\title{
Using Synchrotron Radiation X-ray Fluorescence (SRXRF) to Assess the Impacts of Shipping Emissions \\ on the Variations of $\mathrm{PM}_{10}$-bound Elemental Species
}

Aerosol and Air Quality Research

\section{OPEN ACCESS}

Received: February 6, 2021

Revised: July 8, 2021

Accepted: July 12, 2021

${ }^{*}$ Corresponding Author:

Publisher:

Taiwan Association for Aerosol Research

ISSN: $1680-8584$ print

ISSN: 2071-1409 online

Copyright: The Author's institution. This is an open access article distributed under the terms of the Creative Commons

Attribution License (CC BY 4.0), which permits unrestricted use, distribution, and reproduction in any medium, provided the original author and source are cited.

\section{Siwatt Pongpiachan ${ }^{1 *}$, Nichada Jearanaikoon ${ }^{2}$, Kanjana Thumanu ${ }^{2}$, Jureerat Pradubsri ${ }^{2}$, Ratchadaporn Supruangnet ${ }^{2}$, Chaisri Tharasawatpipat ${ }^{3}$, Muhammad Zaffar Hashmi ${ }^{4}$, Ronbanchob Apiratikul ${ }^{3}$}

\author{
${ }^{1}$ NIDA Center for Research \& Development of Disaster Prevention \& Management, School of \\ Social and Environmental Development, National Institute of Development Administration \\ (NIDA), Bangkok 10240, Thailand \\ ${ }^{2}$ Synchrotron Light Research Institute (Public Organisation), Nakhon Ratjasima 30000, Thailand \\ ${ }^{3}$ Department of Environmental Science, Suan Sunandha Rajabhat University, Bangkok 10300, \\ Thailand \\ ${ }^{4}$ Department of Chemistry, COMSATS University Islamabad, Islamabad 45550, Pakistan
}

\section{ABSTRACT}

Shipping activities significantly contribute to global atmospheric pollutant emissions. Numerous studies have used synchrotron X-ray fluorescence spectroscopy (SRXRF) to identify elemental species in atmospheric particles, yet few studies have applied this technique for assessing $\mathrm{PM}_{10^{-}}$ bound chemical species from shipping emissions. In this study, we conducted simultaneous sampling of $\mathrm{PM}_{10}$ at three air quality observation sites located close to Laem Chabang Sea Port (LCSP) from 24 May to 27 June 2020. The $\mathrm{PM}_{10}$ samples were then chemically characterised using SRXRF at the Beam Line 5.1 Wiggler (BL5.1W) in the Siam Photon Source, Synchrotron Light Research Institute (Nakhon Ratchasima, Thailand). We identified unique features in the SRXRF spectra of $\mathrm{PM}_{10}$ samples collected from the site adjacent to LCSP. The average percentage contributions of selected metals at LCSP occurred in the order of $\mathrm{Fe}>\mathrm{Cu}>\mathrm{Te}>\mathrm{As}>\mathrm{Br}>\mathrm{Kr}>$ $\mathrm{Mn}>\mathrm{Cr}>\mathrm{Ni}>\mathrm{V}>\mathrm{Ti}>\mathrm{P}>\mathrm{Se}>\mathrm{S}>\mathrm{Cl}$, which is in good agreement with the results of previous studies conducted in Bangkok. Although some previous studies highlight the importance of $\mathrm{V} / \mathrm{Fe}$ as the diagnostic binary ratio that can be used as a chemical proxy for categorizing shipping related particles, this application can be problematic-particularly in the atmospheric environment with high contents of iron-rich dust aerosols. In stead of employing $\mathrm{V} / \mathrm{Fe}$, the diagnostic binary ratios of As/ $\mathrm{V}$ and $\mathrm{Se} / \mathrm{V}$ can be considered as alternative geochemical tracers for classifying shipping emissions associated aerosols. By applying the concept of enrichment factor (EF), Se is exceedingly enriched in all observatory sites indicating that industrial emissions were the dominant contributor of Se at the ambient air of Lam Chabang. Hierarchical cluster analysis (HCA) successfully classify a group of $\mathrm{V}, \mathrm{Ti}, \mathrm{Ga}$, and $\mathrm{Ni}$ at all sampling sites, which may be caused by shipping activities coupled with industrial emissions.

Keywords: $\mu$-SRXRF spectra, $\mathrm{PM}_{10}$, Rare elements, Heavy metals, Shipping emissions

\section{INTRODUCTION}

Although there are many advantages, it is necessary to identify and minimise the various environmental impacts from commercial shipping transportation. For instance, low-frequency noise levels from ocean freight shipping activities enhanced by up to $3 \mathrm{~dB}$ per decade from the mid-1960s to 2000 (McDonald et al., 2006). Shipping activities also significantly contribute to atmospheric carbon dioxide $\left(\mathrm{CO}_{2}\right)$, methane $\left(\mathrm{CH}_{4}\right)$, nitrous oxide $\left(\mathrm{N}_{2} \mathrm{O}\right)$, and black carbon $(B C)$ 
emissions (Olmer et al., 2017). These emissions are expected to increase with the growth of maritime container shipping, which is expected to enhance the melting of ice and snow-especially in the Arctic region (Corbett et al., 2010). Sulphate aerosol emissions in the Mediterranean and the English Channel/North Sea increased by $60 \%$ and $30-35 \%$, respectively (Aksoyoglu et al., 2016). Ocean freight shipping activities also influence the contents of atmospheric chemical species and enhance the deposition of nitrogen and sulphur compounds along the main shipping routes (Aksoyoglu et al., 2016).

Numerous investigations have highlighted the need to quantitatively estimate the contribution of shipping emissions to the concentrations of persistent organic pollutants (POPs) and other elemental species (Pongpiachan et al., 2015; Wen et al., 2018; Xiao et al., 2018; Zhao et al., 2019, 2020). For example, a significant enhancement of $\mathrm{PM}_{10}$-bound polycyclic aromatic hydrocarbons (PAHs) and the mutagenic index (MI) were detected during the docking period in the port area of Rayong province, Thailand (Pongpiachan et al., 2015). Moreover, the atmospheric contents of $17 \mathrm{PAHs}, 12$ nitro-PAHs, and 4 oxygenated-PAH congeners were successfully characterised in $\mathrm{PM}_{2.5}$ emitted from an inland-river bulk freighter and an ocean-going passenger vessel (Zhao et al., 2019). PAH emission factors also show remarkable differences between different fuel types (e.g., heavy fuel oil (HFO) and marine diesel oil (MDO)) in the engine loading of an ocean-going cargo vessel (Zhao et al., 2020). A single particle aerosol mass spectrometer was used to classify the ion mass spectra (with positive and negative ion information) of marine shipping emissions at berth (Xiao et al., 2018). Due to the presence of $\mathrm{V}$ in fuels such as HFO, the positive $\left(\mathrm{V}^{+}\right)$and oxidised $\left(\mathrm{VO}^{+}\right)$ions of $\mathrm{V}$ are considered to be strong chemical tracers of shipping emissions (Xiao et al., 2018). $\mathrm{Ni}$ is also considered as a trace marker for HFO combustion in ships (Wen et al., 2018).

In recent years, atomic absorption spectroscopy (AAS) and inductively coupled plasma mass spectrometry (ICP-MS) have been frequently used to chemically characterise the elemental species in aerosols (Ahmad et al., 2019; Almeida et al., 2020; Báez et al., 2007; Leili et al., 2008; Pongpiachan et al., 2017, 2018; Pongpiachan and lijima, 2016). For instance, the origin of trace elements and heavy metals in $\mathrm{PM}_{10}$ and TSP has been widely investigated globally, such as in Khyber Pakhtunkhwa, Pakistan (Ahmad et al., 2019); Florianópolis, Brazil (Almeida et al., 2020); south of Mexico City, Mexico (Báez et al., 2007); central Tehran, Iran (Leili et al., 2008); and Bangkok, Thailand (Pongpiachan et al., 2017, 2018; Pongpiachan and lijima, 2016). X-ray fluorescence (XRF) has also been used to chemically analyse aerosols due to its high sensitivity, non-destructive detection, multi-elemental competence, low sample requirement, and the potential to detect amorphous structures (e.g., solid, liquid) at atmospheric pressure (Rivers et al., 1991). The recent improvement of $\mu$-synchrotron radiation XRF ( $\mu$-SRXRF) has enabled the continuous identification of elemental species in $\mathrm{PM}_{10}$ at $\mathrm{ppm}$ concentrations due to its comparatively high X-ray flux $\left(10^{11-14} \mathrm{ph} \mathrm{s}^{-1}\right)$ and wide energy spectrum (5-30 keV), which covers the binding energies and enables the detection of all elements (Lahiri et al., 2020). As a result, $\mu$-SRXRF has been frequently used to investigate the chemical composition of aerosol particles in both urban and semi-urban sites around the world (Bukowiecki et al., 2005, 2008; Cozzi et al., 2012; López et al., 2011). Numerous studies have demonstrated the promising application of $\mu$-SRXRF for identifying elemental species in atmospheric particles; however, little is known about its application for assessing chemical species in $\mathrm{PM}_{10}$ from shipping emissions. Overall, the main aims of this study were to (i) chemically characterise the elemental species in $\mathrm{PM}_{10}$ using $\mu$-SRXRF, (ii) investigate the impact of shipping emissions on the variability of $\mathrm{PM}_{10}$-bound elemental species, and (iii) apply advanced statistical tools to determine the source apportionment of $\mathrm{PM}_{10}$.

\section{MATERIALS AND METHODS}

\subsection{Sampling Sites}

We selected three sampling stations located in Sriracha district, Chon Buri Province, Thailand, due to their distance from Laem Chabang Sea Port (LCSP) (Fig. 1): (1) Laem Chabang Temple Air Quality Observatory Site (LCAS: $\left.13^{\circ} 4^{\prime} 55.42^{\prime \prime} \mathrm{N} 100^{\circ} 52^{\prime} 51.64^{\prime \prime} \mathrm{E}\right),(2)$ Laem Thong Temple Air Quality Observatory Site (LTAS: $13^{\circ} 5^{\prime} 29.40^{\prime \prime} \mathrm{N} 100^{\circ} 55^{\prime} 50.12^{\prime \prime} \mathrm{E}$ ), and (3) Waterworks Authority Air Quality Observatory Site (WAAS: $\left.13^{\circ} 6^{\prime} 6.26^{\prime \prime} \mathrm{N} 100^{\circ} 58^{\prime} 14.84^{\prime \prime} \mathrm{E}\right)$. As LCAS is the closest monitoring site to LCSP, the $\mathrm{PM}_{10}$ samples from this site were assumed to represent shipping emissions. In 


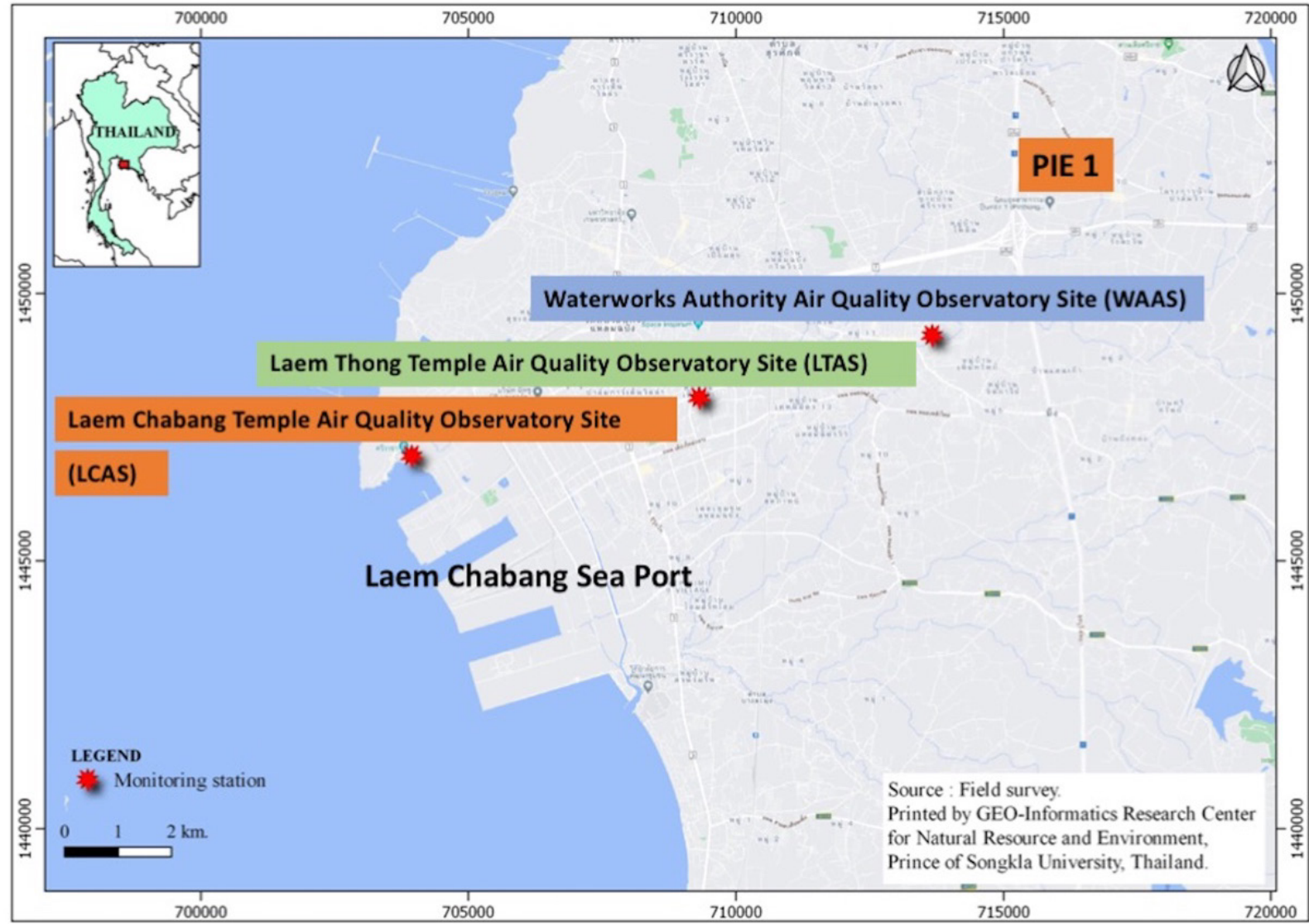

Fig. 1. A map of three air quality observatory sites of this study.

contrast, WAAS is only $3 \mathrm{~km}$ southwest of the Pinthong Industrial Estate 1 (PIE1) and is the farthest site from LCSP (see Fig. 1). Pinthong Industrial Park Co., Ltd. (founded in 1995) constructed the PIE1 on an area of 207 rai (i.e., 331,200 $\mathrm{m}^{2}$ ) in Chon Buri Province in collaboration with the Industrial Estate Authority of Thailand. PIE1 consists of many factories producing various products, including oil filters, engineering plastic parts, plastic compound beads, dye pigments, electronic appliances, iron, stainless steel, alumina ceramic fibre, wooden pallets, wooden boxes, and industrial electric cranes. Hence, the samples from WAAS were assumed to represent industrial emissions from PIE1 factories. Finally, LTAS is located in a residential area, and the samples from this site were representative of urban background emissions.

\section{2 $\mathrm{PM}_{10}$ Collection}

Instantaneous $\mathrm{PM}_{10}$ sampling was conducted at all three sites from 24 May (Sunday) to 27 June (Saturday), 2020. Continuous $24 \mathrm{hr} \mathrm{PM}_{10}$ sampling began at 10:00-11:00 AM each day using a high-volume air sampler (Thermo Scientific: G3101) with a constant flow rate of $40 \mathrm{ft}^{3} \mathrm{~min}^{-1}$ $\left(\sim 1.1 \mathrm{~m}^{3} \mathrm{~min}^{-1}\right)$. $\mathrm{PM}_{10}$ sampling was performed without the use of the sampler's air pump for the first three (24-27 May, 2020) and last three days (24-27 June, 2020). All PM10 samples were collected on quartz microfibre filters (QMFs) with a pore size of $2.2 \mu \mathrm{m}$, a thickness of $0.47 \mathrm{~mm}$, and dimensions of $203 \times 254 \mathrm{~mm}$. The filters were placed in a desiccator for $24 \mathrm{~h}$ prior to weighing to avoid water vapour contamination. The weights of the filters before and after sampling were measured by an electronic balance (Mettler Toledo ME204). The air temperature (AT) and relative humidity $(R H)$ were carefully monitored using the meteorological sensor, which combined ambient air temperature, relative humidity, and barometric pressure in a single device (Bosch BME280). In addition, an air pollution rose of $\mathrm{PM}_{10}$ coupled with a wind rose detected at the air quality observatory site of Pollution Control Department (PCD), Ministry of Natural Resources and Environment (MNRE) located at Laem Chabang stadium from 24 $4^{\text {th }}$ May 2020 to $27^{\text {th }}$ June 2020 were illustrated at Figs. S1-S3. 


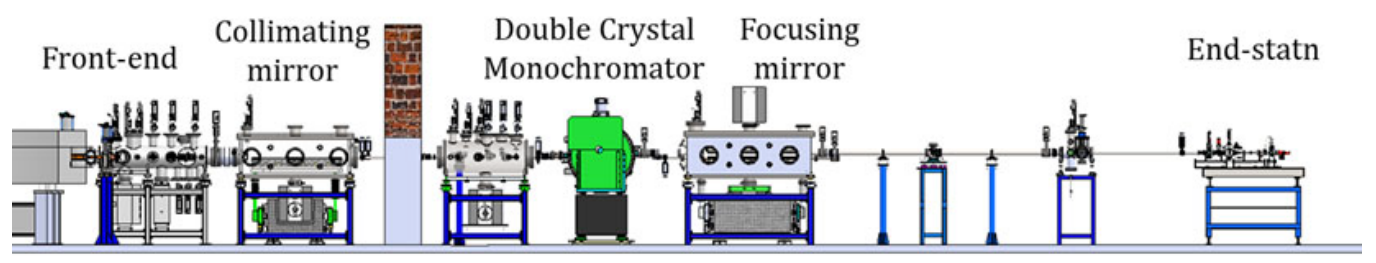

Fig. 2. Schematic Diagram of Beamline 5.1W: X-ray Absorption Spectroscopy \& Microbeam X-ray Fluorescence (XAS/ $\mu$ XRF) (ASEAN Beamline).

\section{$2.3 \mu$-SRXRF Analysis}

The elemental composition of $\mathrm{PM}_{10}$ on the filter papers was analysed by SRXRF at the Beam Line 5.1 Wiggler (BL5.1W) in the Siam Photon Source, Synchrotron Light Research Institute, Nakhon Ratchasima, Thailand (Fig. 2). Each QMF sample was randomly cut into three pieces to sizes of approximately $1 \times 1 \mathrm{~cm}$ and then sandwiched with Kapton tape and attached to the sample holder, which was positioned at $45^{\circ}$ to the direction of the incoming X-ray photons (Fig. S1). The sample was exposed to a $15 \mathrm{keV}$ monochromatic X-ray beam with a size of $2 \times 2 \mathrm{~mm}$, originating from a pair of $\mathrm{Si}$ (311) crystals for $5 \mathrm{~min}$. The fluorescence photons generated from the irradiated sample's surface were detected by the Vortex $\mathrm{EM}^{\circledR}$ silicon drift detector (SDD), which was positioned $30 \mathrm{~mm}$ away from the sample surface and perpendicular to the SR beam. The measurement was conducted in an air environment, with three replicates per filter paper sample. The spectral analysis (i.e., energy calibration, peak identification, and peak fitting) was conducted using PyMCA version 5.5.4 (Solé et al., 2007). Relative elemental concentrations were calculated from the peak fit area of each element on the obtained spectra. In addition, all advanced statistical analyses were conducted using IBM SPSS Statistics 23.

\section{RESULTS AND DISCUSSION}

\subsection{Meteorological Data}

Chonburi Province is situated $12 \mathrm{~m}$ above sea level. According to the Köppen climate classification, Chonburi Province is categorised as tropical savanna climate, or tropical wet and dry climate (Barton, 1962). The measured atmospheric PM10 contents at LCAS, LTAS, and WAAS were $53 \pm$ $82 \mu \mathrm{g} \mathrm{m}^{-3}, 29 \pm 39 \mu \mathrm{g} \mathrm{m}^{-3}$, and $29 \pm 13 \mu \mathrm{g} \mathrm{m}^{-3}$, respectively, and the ambient air temperatures were $34.2 \pm 1.72^{\circ} \mathrm{C}, 31.0 \pm 1.19^{\circ} \mathrm{C}$, and $31.6 \pm 1.34^{\circ} \mathrm{C}$, respectively. The average $R H$ of the three sampling sites was $62.3 \pm 6.3 \%$.

\subsection{SRXRF Spectra and Percentage Contributions of Elemental Species}

Numerous studies have quantitatively characterised the elemental compositions of aerosols to evaluate the emissions strength of contaminant sources (Ahmad et al., 2019; Almeida et al., 2020; Báez et al., 2007; Leili et al., 2008; Pongpiachan et al., 2017, 2018; Pongpiachan and lijima, 2016); however, innovative analytical techniques are still required to enhance data interpretation. In this study, we used the SRXRF spectra to distinguish shipping emission aerosols from urban background particles. LCAS, LTAS, and WAAS were classified into three main groups: Port Area, Urban Background, and Industrial Area, respectively (see Fig. 1). The average SRXRF spectra of the three clusters were carefully examined and compared (See Fig. 3). We determined the atmospheric percentage contributions of 16 selected elemental species from a total of 84 samples collected at LCAS, LTAS, and WAAS from 27 May to 23 June 2020, as shown in Fig. 4. As all PM10 samples were collected on QMFs, all SRXRF spectra of the aerosol samples were subtracted from those of the field blanks.

All three clusters exhibited similar spectral features. We observed four noticeable characteristics that were mutually inclusive to all spectra. First, we observed high contributions from three major elements in all samples, namely Fe ( $\mathrm{K}_{\alpha}$ at $6.404 \mathrm{keV}, \mathrm{K}_{\beta}$ at $\left.7.058 \mathrm{keV}\right), \mathrm{Cu}\left(\mathrm{K}_{\alpha}\right.$ at $8.048 \mathrm{keV}$, $\mathrm{K}_{\beta}$ at $\left.8.905 \mathrm{keV}\right)$, and $\mathrm{As}\left(\mathrm{K}_{\alpha}\right.$ at $10.543 \mathrm{keV}, \mathrm{K}_{\beta}$ at $\left.11.726 \mathrm{keV}\right)$, with total contributions of $87 \%$, $83 \%$, and $83 \%$ for LCAS, LTAS, and WAAS, respectively (See Fig. 4). Second, all PM10 samples showed moderate contributions from $\mathrm{Br}\left(\mathrm{K}_{\alpha}\right.$ at $11.924 \mathrm{keV}, \mathrm{K}_{\beta}$ at $\left.13.291 \mathrm{keV}\right), \mathrm{Kr}\left(\mathrm{K}_{\alpha}\right.$ at $12.649 \mathrm{keV}, \mathrm{K}_{\beta}$ at 


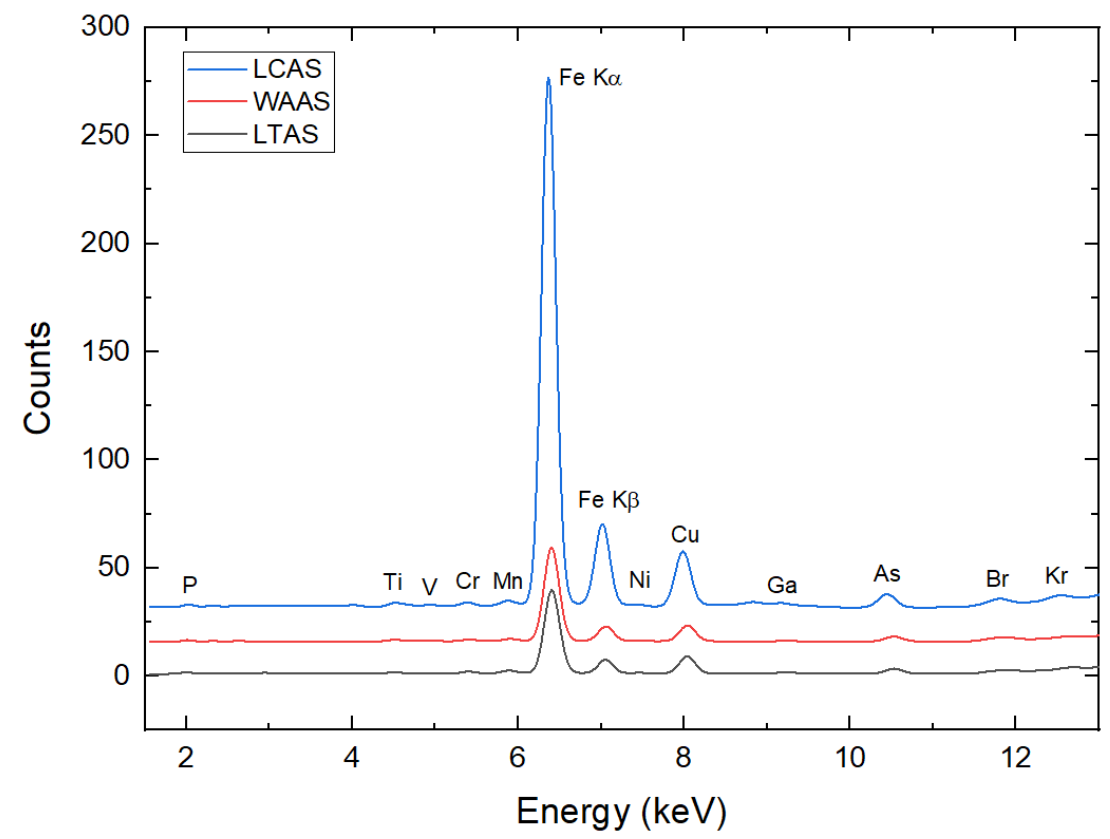

Fig. 3(A). Spectrum of $\mu$-SRXRF in PM 10 collected at LCAS, LTAS, and WAAS from May 2020 to June 2020.

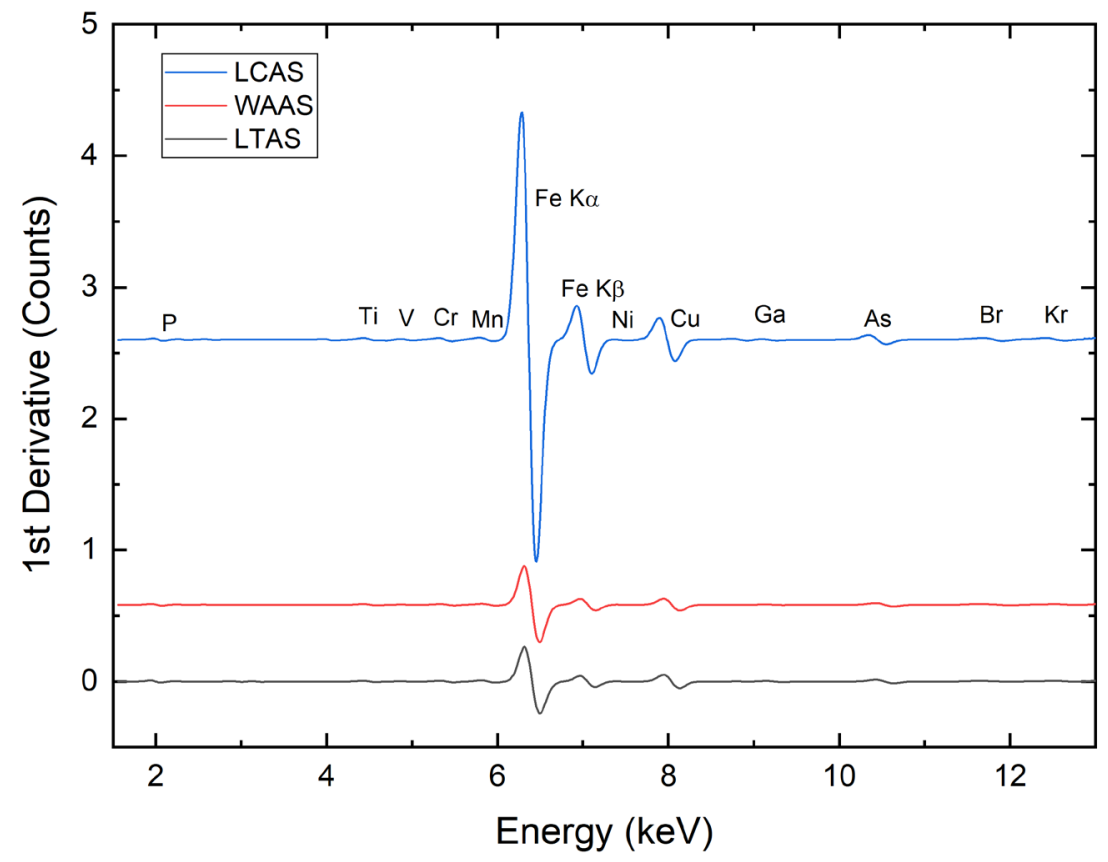

Fig. 3(B). First derivative of $\mu$-SRXRF spectrum in $\mathrm{PM}_{10}$ collected at LCAS, LTAS, and WAAS from May 2020 to June 2020.

$14.112 \mathrm{keV}), \mathrm{Mn}\left(\mathrm{K}_{\alpha}\right.$ at $5.899 \mathrm{keV}, \mathrm{K}_{\beta}$ at $\left.6.490 \mathrm{keV}\right)$, and $\mathrm{Cr}\left(\mathrm{K}_{\alpha}\right.$ at $5.415 \mathrm{keV}, \mathrm{K}_{\beta}$ at $\left.5.947 \mathrm{keV}\right)$, with total contributions of $6.9 \%, 8.2 \%$, and $8.9 \%$ for LCAS, LTAS, and WAAS, respectively. Third, Ni ( $\mathrm{K}_{\alpha}$ at $7.478 \mathrm{keV}, \mathrm{K}_{\beta}$ at $\left.8.265 \mathrm{keV}\right), \mathrm{V}\left(\mathrm{K}_{\alpha}\right.$ at $4.925 \mathrm{keV}, \mathrm{K}_{\beta}$ at $\left.5.427 \mathrm{keV}\right), \mathrm{Ti}\left(\mathrm{K}_{\alpha}\right.$ at $4.510 \mathrm{keV}, \mathrm{K}_{\beta}$ at $4.932 \mathrm{keV}), \mathrm{P}\left(\mathrm{K}_{\alpha}\right.$ at $2.014 \mathrm{keV}, \mathrm{K}_{\beta}$ at $\left.2.139 \mathrm{keV}\right)$, Se $\left(\mathrm{K}_{\alpha}\right.$ at $11.222 \mathrm{keV}, \mathrm{K}_{\beta}$ at $\left.12.496 \mathrm{keV}\right), \mathrm{S}\left(\mathrm{K}_{\alpha}\right.$ at $2.308 \mathrm{keV}, \mathrm{K}_{\beta}$ at $\left.2.464 \mathrm{keV}\right)$, and $\mathrm{Cl}\left(\mathrm{K}_{\alpha}\right.$ at $2.622 \mathrm{keV}, \mathrm{K}_{\beta}$ at $2.816 \mathrm{keV}$ ) occurred at extremely low levels, with total contributions of $2.3 \%, 2.9 \%$, and $2.67 \%$ for LCAS, LTAS, and WAAS, respectively. Based on these results, we found that all elemental species in the $\mathrm{PM}_{10}$ samples shared comparable spectral features. 


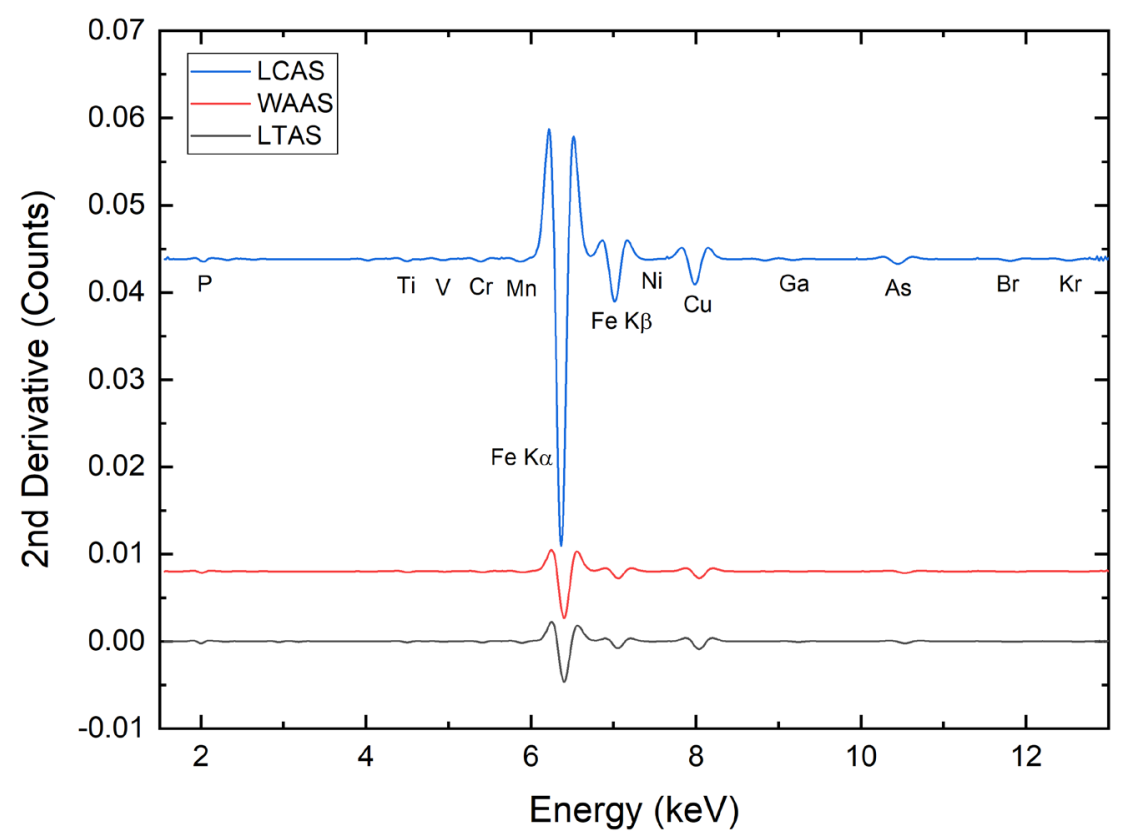

Fig. 3(C). Second derivative of $\mu$-SRXRF spectrum in $\mathrm{PM}_{10}$ collected at LCAS, LTAS, and WAAS from May 2020 to June 2020.

Although all $\mathrm{PM}_{10}$ samples showed relatively similar SXRF spectral distribution patterns in the photon energy range of $2-12 \mathrm{keV}$, noticeable comparative alterations can be magnified by calculating the first and second-order derivative of the raw spectra (Bhagavathy et al., 1991; Hong et al., 2019; Li et al., 2020; Pongpiachan et al., 2013). The calculation of the first-order derivative provides curves with peaks indicating the maximum alteration rate of the original spectral curves, while horizontal lines indicate no fluctuation in the slope of the spectral curves. As illustrated in Fig. 3(B), LCAS has a unique first-order derivative spectral curve, which differs from that of LTAS and WAAS. The LCAS first-order derivative spectral curve can be categorised by its major positive and negative peaks between 6 and $7 \mathrm{keV}$ (Fig. 3(B)). Similarly, the LCAS second-order derivative spectral curve showed two major positive peaks and one major negative peak between 6 and $7 \mathrm{keV}$ (Fig. 3(C)). Moreover, the absence of major positive peaks for $\mathrm{Ga}, \mathrm{As}, \mathrm{Br}$, and $\mathrm{Kr}$ at the energy range of 8-12 keV in all spectral curves for both first and the second-order derivative forms suggests that these elements occurred at extremely low levels. In addition, the absence of major positive peaks for $\mathrm{Ti}, \mathrm{V}, \mathrm{Cr}$, and $\mathrm{Mn}$ at the energy range of 4-6 keV suggests that these elements had comparatively low percentage contribution.

\subsection{Diagnostic Binary Ratios and Enrichment Factors}

As, $\mathrm{Cr}, \mathrm{Cu}, \mathrm{Mn}, \mathrm{Ni}$, and $\mathrm{Pb}$ are key species representing coal combustion (Cercasov et al., 1998; Deng et al., 2014; Galvagno et al., 2002; Manoli et al., 2002; Pastuszka et al., 2010; Tian et al., 2010, 2012; Weckwerth, 2001; Xia and Gao, 2011; Yang et al., 2003; Zhang et al., 2009), and As, $\mathrm{Cu}, \mathrm{Mn}$, and $\mathrm{Zn}$ are potential chemical proxies for smelting furnaces and steel smelting (Querol et al., 2006; Yang et al., 2003). Moreover, $\mathrm{V}$ and Ni are widely used as indicators of heavy oil combustion, such as that of HFO in ship engines (Cercasov et al., 1998; Chu-Van et al., 2020; Tian et al., 2012, 2013). As illustrated in Table 1, the diagnostic binary ratios of Ni/V collected from LCAS, LTAS, and WAAS were 1.6,1.2, and 1.0, respectively. These values are similar to those of urban background samples collected from Antwerpen (1.4), Gent (1.4), Bruges (1.2), and Oostende (1.1) in Belgium (Maenhaut et al., 2016), as well as that of traffic road samples collected from Hornsgatan in Stockholm (1.2), Sweden (Johansson et al., 2009). In contrast, an exceedingly high Ni/V ratio of 5.6 was detected at the Daejeon Industrial Complex (DIC) in South Korea (Lim et al., 2010). As $\mathrm{Ni}$ is a marker element of coal combustion and $\mathrm{V}$ is a chemical tracer of oil burning (Lim et al., 2005), the comparatively high $\mathrm{Ni} / \mathrm{V}$ is likely due to the contribution of coal combustion for power generation in the DIC. According to the coal information overview provided by the 


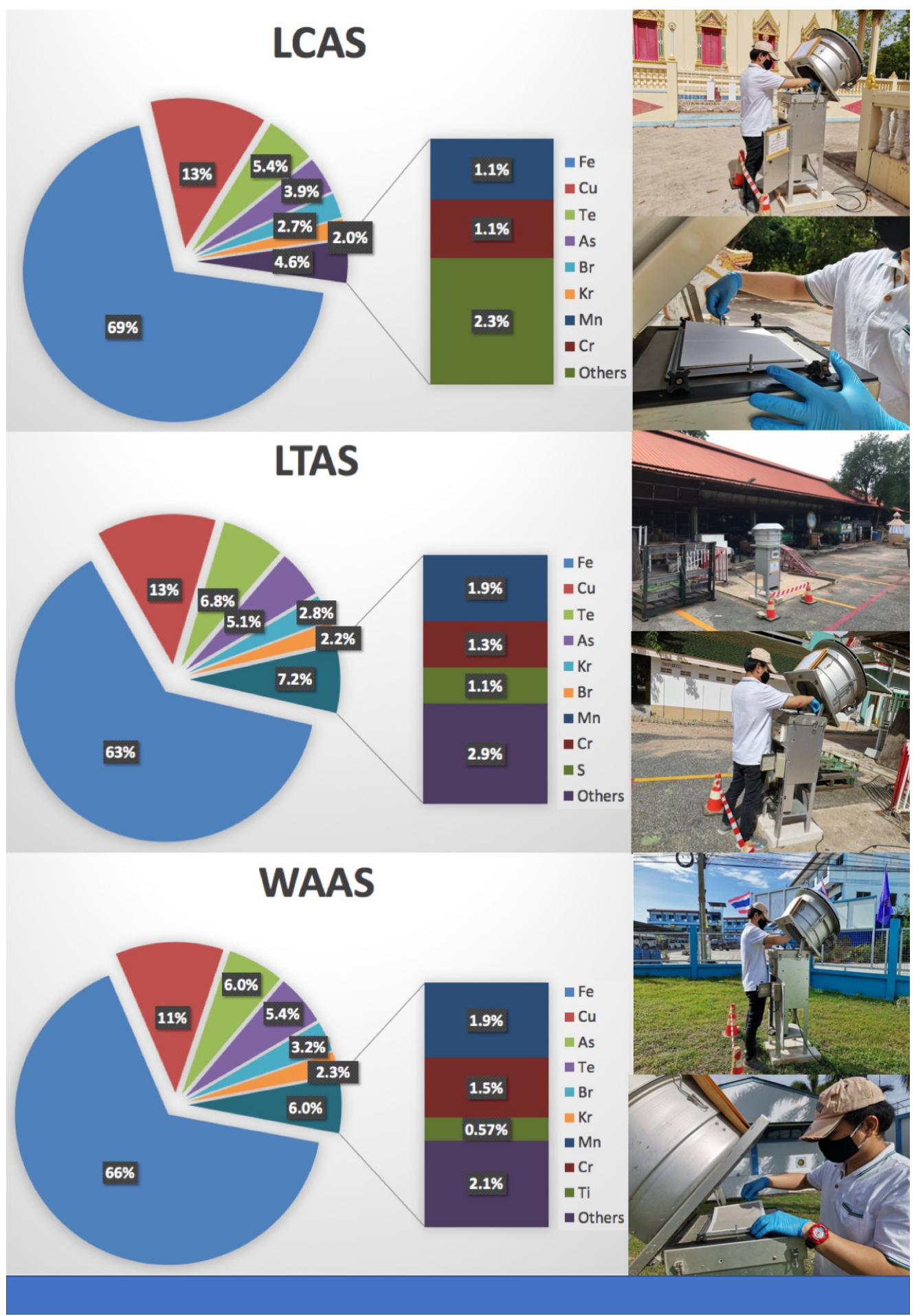

Fig. 4. Percentage contribution of selected element species in PM10 collected at LCAS, LTAS, and WAAS from May 2020 to June 2020.

International Energy Agency, South Korea has shown an increasing trend in total coal imports by major importers from 1978 to 2019 (https://www.iea.org/reports/coal-information-overview). In agreement, South Korea ranked in the top 10 electricity producing countries in 2014 (Di Gianfrancesco, 2017).

We also assessed the diagnostic binary ratios of $\mathrm{V} / \mathrm{Fe}, \mathrm{As} / \mathrm{V}$, and $\mathrm{Se} / \mathrm{V}$ in this study. Fe is a major crustal element (e.g., $\mathrm{Al}, \mathrm{Si}, \mathrm{K}, \mathrm{Ca}$, and $\mathrm{Ti}$ ) and is predominantly observed in aerosols (Gaonkar et al., 2020; Lawson and Winchester, 1979); hence, V/Fe can be used as an effective chemical proxy 


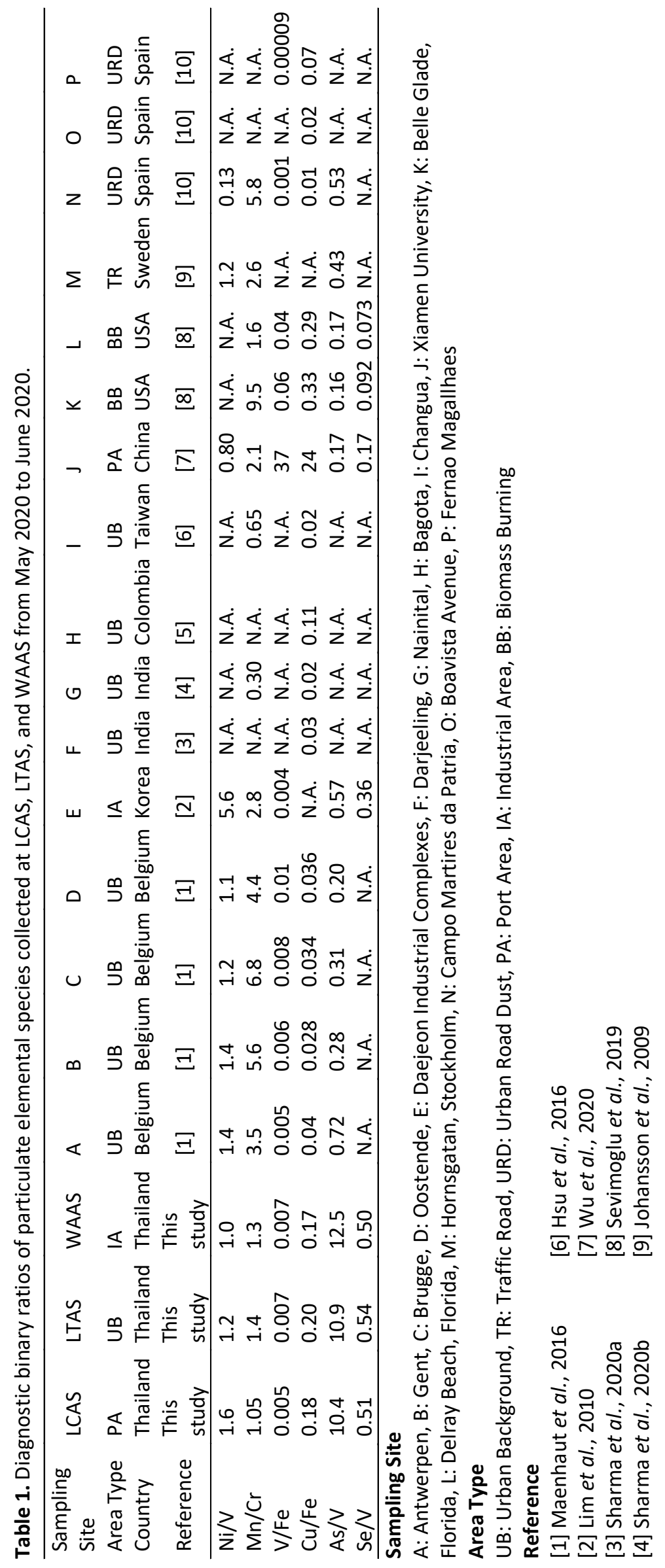


for classifying shipping emission aerosols. As displayed in Table 1, the V/Fe value at LCAS was almost 7,400 times lower than that of the port area in China (Wu et al., 2020). Fe was found to be the second highest element in $\mathrm{PM}_{10}$ in ambient air in Bangkok (Pongpiachan and lijima, 2016), which is located $125 \mathrm{~km}$ northwest of LCSP. The application of V/Fe as a chemical tracer of shipping emissions can therefore be problematic-especially in ambient air with high concentrations of ironrich dust particles. In contrast, the diagnostic binary ratios of As/V at LCAS, LTAS, and WAAS were excessively high compared with that of other aerosol types. For instance, As/V at LCAS was 14, 18, and 65 times higher than those detected at Antwerpen (Maenhaut et al., 2016), DIC (Lim et al., 2010), and Belle Glade (Florida) (Sevimoğlu and Rogge, 2019), respectively. Similarly, Se/V at LCAS was 1.4, 5.5, and 7.0 times greater than those observed at DIC (Lim et al., 2010), Belle Glade, and Delray Beach (Florida) (Sevimoğlu and Rogge, 2019), respectively. These findings suggest that the application of some diagnostic binary ratios are potentially inaccurate and must be considered with caution.

The enrichment factor $(E F)$ has been extensively used to assess the contribution of traffic emissions (Pongpiachan et al., 2017; Pongpiachan and lijima, 2016; Taghavi et al., 2019), industrial releases (Almasoud et al., 2015; Mingorance et al., 2007), and municipal solid waste combustion (Tang et al., 2015) to selected elemental concentrations. Previous studies have used Fe as a reference element for EF calculations (López et al., 2005; Pongpiachan et al., 2017; Pongpiachan and lijima, 2016). Rudnick (2003) proposed the use of Fe to represent crustal contributions. The $E F$ of element $E$ in a $\mathrm{PM}_{10}$ sample can be described as follows:

$$
E F=\frac{(E / R)_{\text {Air }}}{(E / R)_{\text {Crust }}}
$$

where $R$ is a reference element. An $E F$ of $\sim 1$ suggests that crustal emissions are the major source of the target element, while an $E F$ of $>1$ suggests that anthropogenic activities are the major source of the target element. As displayed in Fig. 5, the logarithms of EF of the 13 selected elemental species in $\mathrm{PM}_{10}$ were categorised into four groups (arbitrary scale):

(i) $\mathrm{S}, \mathrm{Cl}, \mathrm{V}$, and $\mathrm{Mn}$ are not enriched $(\log (E F)<1)$; (ii) $\mathrm{Cr}$, Ni, and $\mathrm{Ga}$ are slightly enriched $(\log (E F)$ close to 1); (iii) $\mathrm{Cu}, \mathrm{As}, \mathrm{Br}$, and $\mathrm{Tl}$ are moderately enriched $(\log (E F)=2-3)$; and (iv) $\mathrm{Se}$ is exceedingly enriched $(\log (E F)>3)$. The above-mentioned distribution patterns were relatively common for the three air quality observation sites. However, we also noted other prominent features. First, we detected an extremely high $\log (E F)$ for Se $(>4)$ at WAAS, which suggests that industrial emissions were the dominant sources of Se at this observation site. This interpretation is reasonable, as the WAAS is located only $3 \mathrm{~km}$ southwest of PIE1 and thus likely represents anthropogenic emissions from the industrial estate. Furthermore, numerous anthropogenic activities, such as coal and oil combustion, refuse incineration, and non-ferrous metal production, have been identified as major sources of atmospheric Se (Mosher and Duce, 1987; Nriagu, 1989; Nriagu and Pacyna, 1988). Second, LCAS showed a different $\log (E F)$ distribution pattern for As, $\mathrm{Se}$, and $\mathrm{Br}$, possibly due to the prevailing shipping emissions at LCSP.

\subsection{Pearson's Correlation Coefficient (PCC) and Hierarchical Cluster Analysis (HCA)}

The Pearson's Correlation Coefficients (PCC) of 16 elements in PM10 collected at LCAS, LTAS, and WAAS are presented in Tables 2-4. The Pearson's correlation results indicated exceedingly strong positive correlations (i.e., $0.9 \leq R<1.0$ ) for Ti vs. $\mathrm{V}$ and $\mathrm{Mn}$ vs. $\mathrm{Cr}$ in $\mathrm{PM}_{10}$ samples collected at WAAS (Table 4). These high positive correlations were likely caused by industrial emissions from PIE1 due to its close proximity to WAAS. Previous studies detected comparatively high As, $\mathrm{Cu}, \mathrm{Mn}$, and $\mathrm{Zn}$ contents emitted from smelting furnaces and steel smelting (Querol et al., 2006; Yang et al., 2003). Moreover, rare earth elements, such as $\mathrm{Cd}, \mathrm{Co}, \mathrm{Cu}, \mathrm{Ni}, \mathrm{Cr}, \mathrm{Pb}$, and $\mathrm{Hg}$, are endocrine disruptors that combine with oestrogen receptors and are also abundant in construction materials and the plastics industry (lavicoli et al., 2009; Philippat et al., 2017). Cr, Mn, and Cu are also used as chemical tracers of iron and steel production (Dai et al., 2015), and both steel production and plastic plants are major industries in PIE1. As $\mathrm{Ni}$ is considered as a chemical marker of industrial emissions from metal-assembly facilities and alloy manufacturing, the strong 


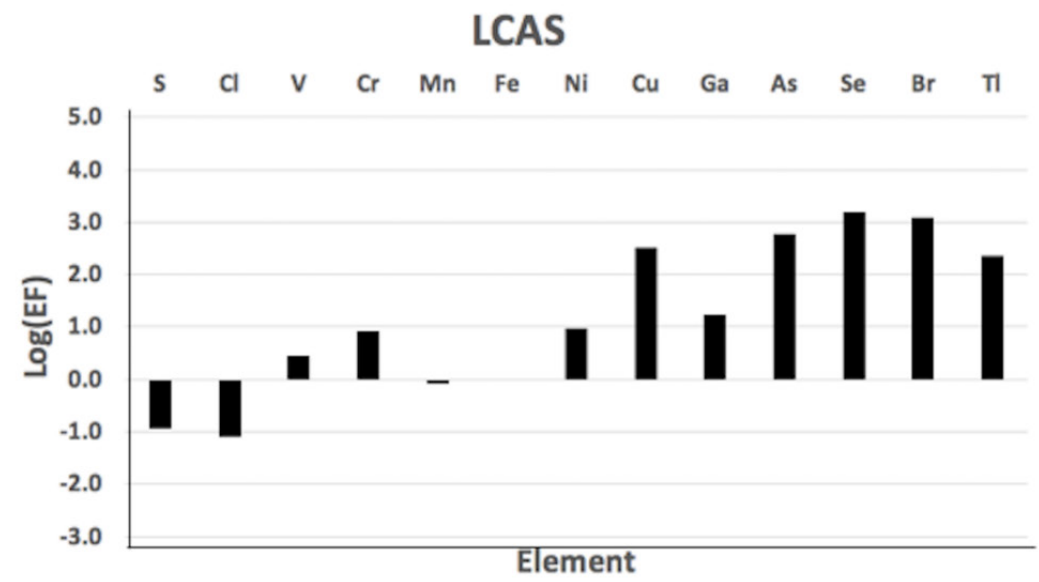

LTAS

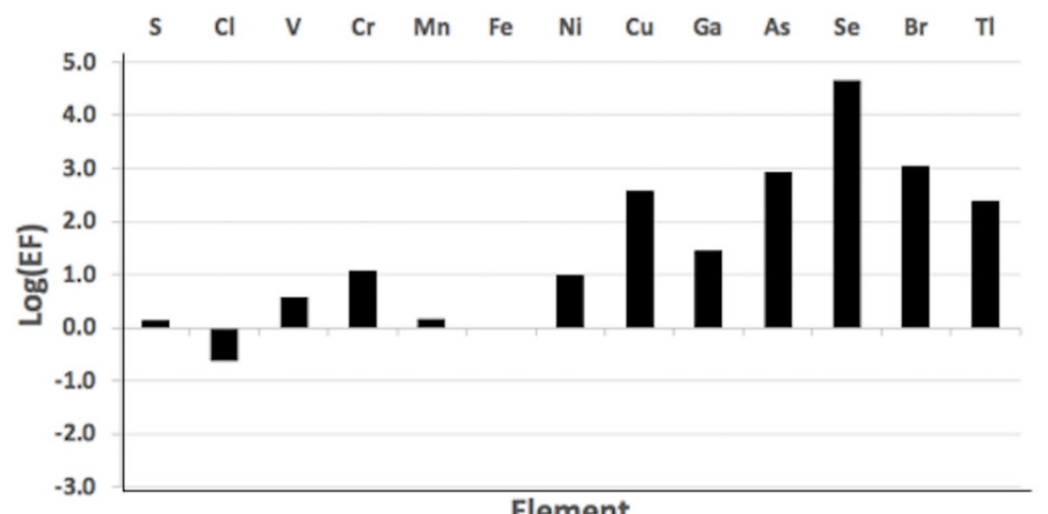

WAAS

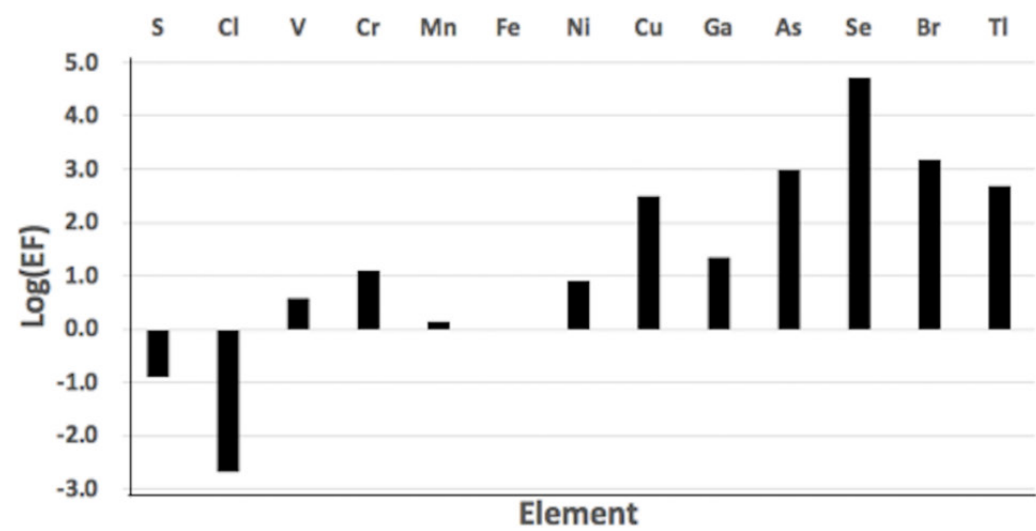

Fig. 5. Logarithms of EF of 13 selected elemental species in $\mathrm{PM}_{10}$ collected at LCAS, LTAS, and WAAS from May 2020 to June 2020.

positive correlations of $\mathrm{Ni}$ vs. $\mathrm{Kr}(0.8 \leq R<0.9)$ and $\mathrm{Ni}$ vs. $\mathrm{Ga}(0.7 \leq R<0.8)$ suggest that $\mathrm{Ni}$ and $\mathrm{Ga}$ can be used as tracers of steel industrial emissions. Notably, we also observed other strong positive correlations between elements at LCAS: $\mathrm{S}$ vs. $\mathrm{P}(0.8 \leq R<0.9), \mathrm{Kr} v \mathrm{Cr} . \mathrm{Cr}(0.8 \leq R<0.9), \mathrm{Kr}$ vs. Ga $(0.8 \leq R<0.9)$, Cu vs. Fe $(0.7 \leq R<0.8)$, Ga vs. $\mathrm{Cr}(0.7 \leq R<0.8)$, As vs. $\mathrm{Cr}(0.7 \leq R<0.8)$, Se vs. Ni $(0.7 \leq R<0.8), \mathrm{Br} v$ s. Ti $(0.6 \leq R<0.7)$, $\mathrm{Br}$ vs. Ti $(0.6 \leq R<0.7)$, Ni vs. $\mathrm{V}(0.6 \leq R<0.7), \mathrm{Ni}$ vs. $\mathrm{Cr}(0.6 \leq R<0.7)$, As vs. $\mathrm{Ga}(0.6 \leq R<0.7)$, $\mathrm{Kr}$ vs. $\mathrm{Mn}(0.6 \leq R<0.7)$, $\mathrm{Te}$ vs. $\mathrm{Cr}(0.6 \leq R<0.7)$, Te vs. Ni $(0.6 \leq R<0.7)$, and Te vs. Se $(0.6 \leq R<0.7)$. These correlations are likely related to the significant contribution of shipping emissions at LCSP, which is located only a few hundred metres from LCAS. 


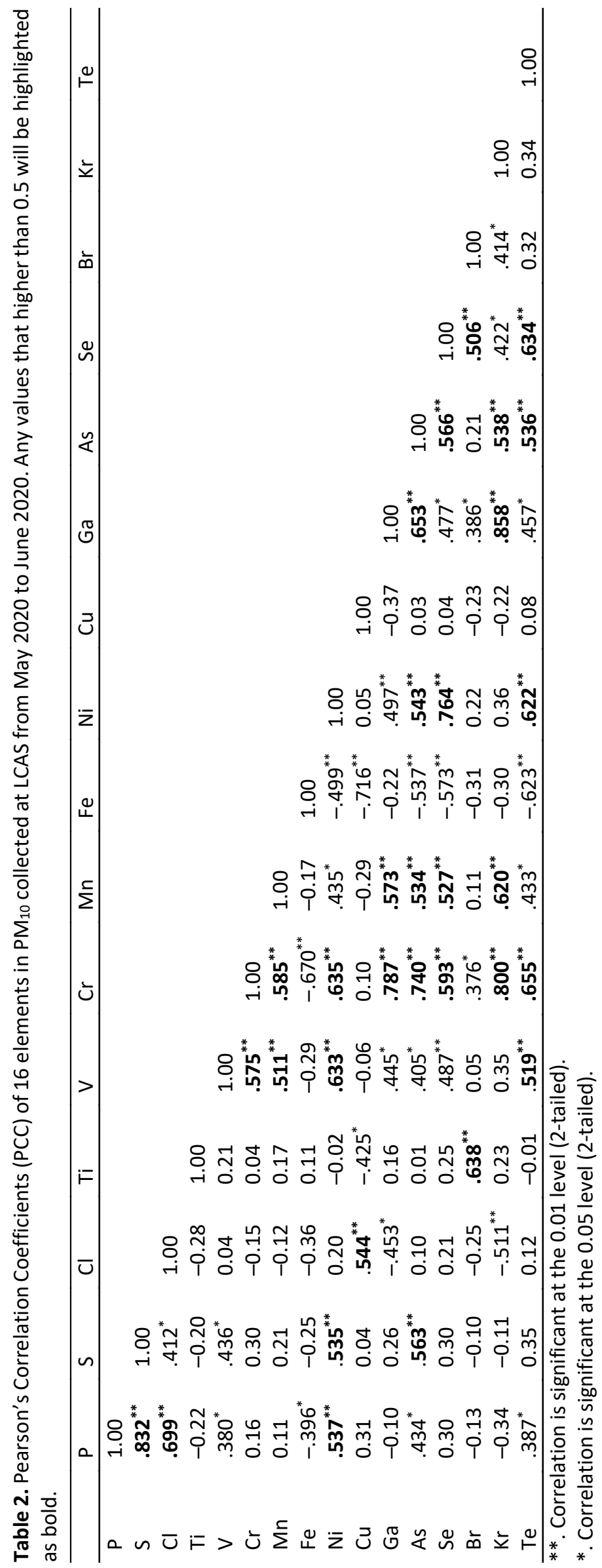




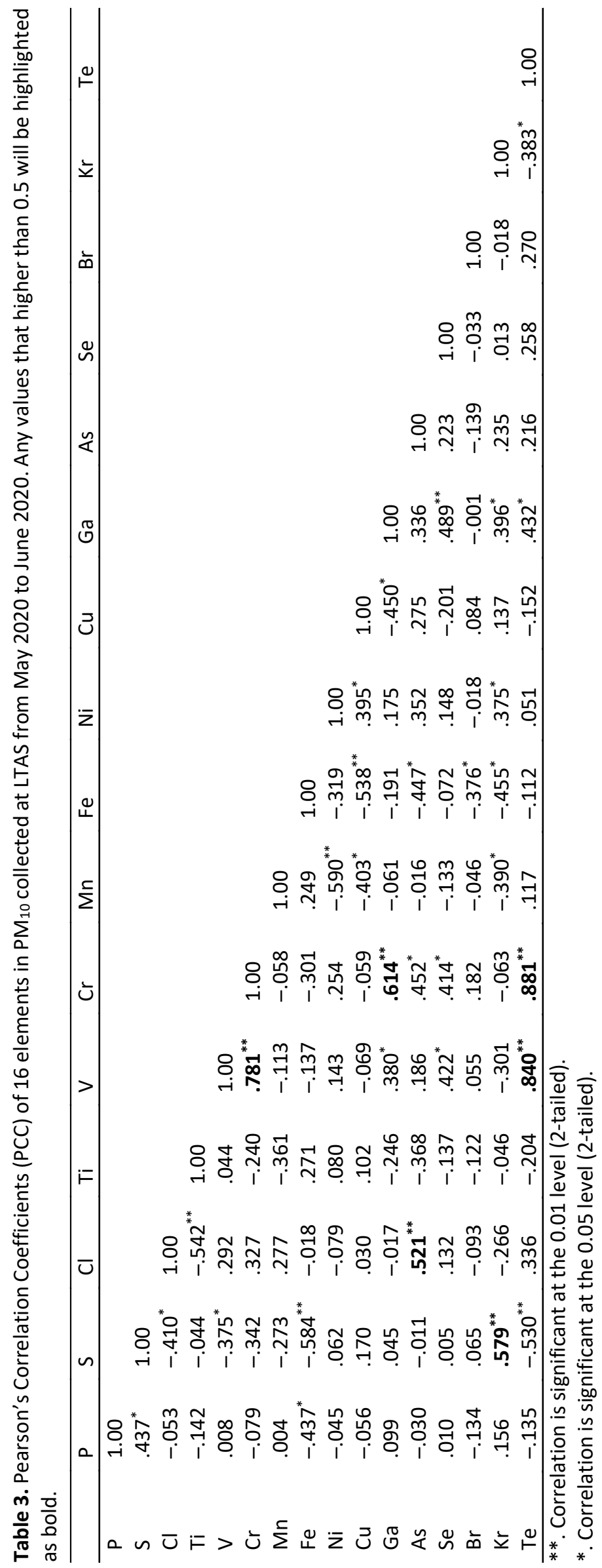




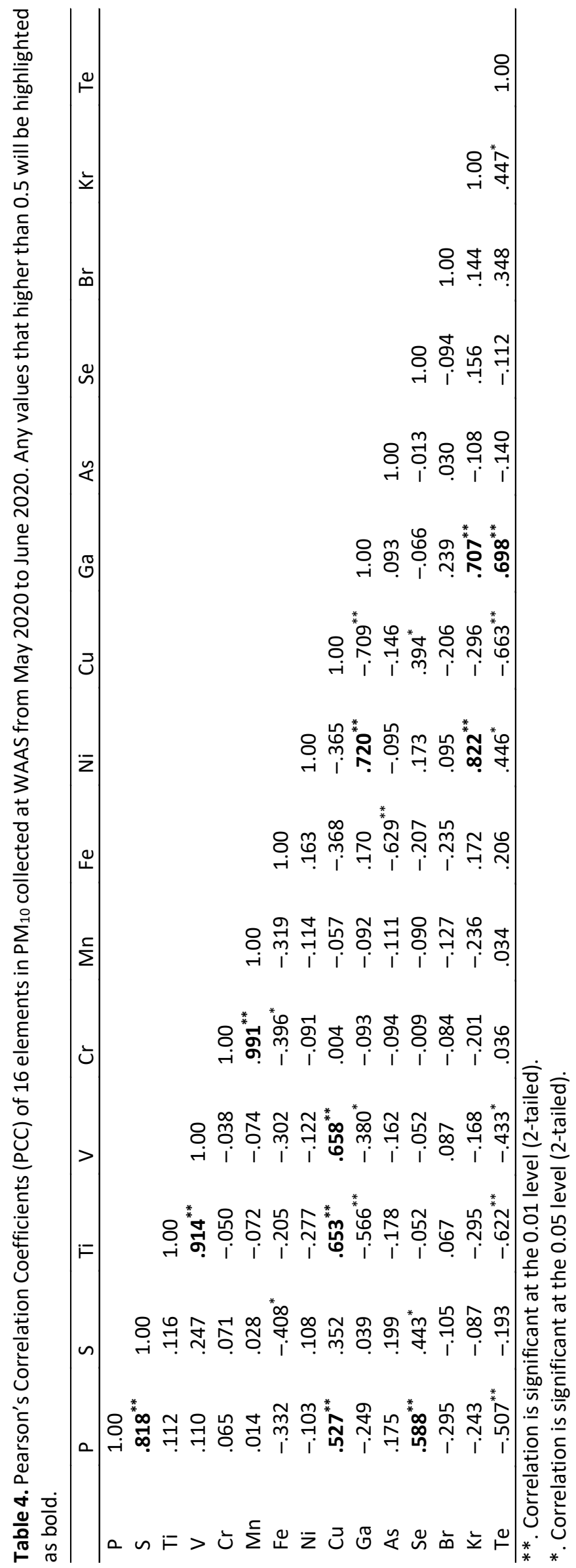


We applied the agglomerative hierarchical clustering algorithm (HCA) on the percentage element contributions from the SRXRF spectra to produce a dendrogram of $\mathrm{PM}_{10}$-bound selected elements from the three air quality observation sites. After importing the data into SPSS Statistics 23, the HCA indicated the presence of three major clusters. The first major cluster consisted of $\mathrm{S}, \mathrm{Cl}$, $\mathrm{Se}, \mathrm{P}, \mathrm{Ni}, \mathrm{Ga}, \mathrm{V}, \mathrm{Ti}, \mathrm{Kr}, \mathrm{Cr}, \mathrm{Mn}, \mathrm{Br}, \mathrm{As}$, and $\mathrm{Te}$; and the second and the third clusters included $\mathrm{Cu}$ and $\mathrm{Fe}$, respectively. As the horizontal axis of the dendrogram reflects the distance of dissimilarity between the clusters, we conclude that the emission source of Fe was entirely different from that of the other elements. This interpretation is consistent with numerous studies identifying crustal emissions as a major source of Fe (Gaonkar et al., 2020; Lawson and Winchester, 1979). Another prominent feature is the proximity of $\mathrm{V}, \mathrm{Ti}, \mathrm{Ga}$, and $\mathrm{Ni}$ at all observation sites, which may be due to the burning of ship engine HFO coupled with the prevalence of heavy oil combustion at PIE1 factories (Cercasov et al., 1998; Chu-Van et al., 2020; Tian et al., 2012, 2013).

\subsection{Principal Component Analysis (PCA)}

PCA is a widely adopted statistical technique for data reduction. Instead of applying several diagnostic binary ratios, PCA decreases the information of various detected parameters into a smaller set of original variables (i.e., selected elemental contents in $\mathrm{PM}_{10}$ samples); this allows for the extraction of principal components (PCS) to assess the relationships between measured parameters. PCA has therefore been widely used as a receptor modelling method to determine the source apportionment of urban air pollutants (Pongpiachan et al., 2015, 2017; Pongpiachan and lijima, 2016). In this study, original parameters were organised into a matrix where individual columns corresponded to a single variable, and each row reflected the number of samples. The PCA was then used to investigate the summarised data in data matrixes (see Tables 5-7). As displayed in Table 5, the PCA patterns of the varimax-rotated components at LCAS were composed of five principal components (PC1, PC2, PC3, PC4, and PC5) that accounted for $23.8 \%$, $17.7 \%, 16.5 \%, 15.5 \%$, and $12.4 \%$ of the total variance, respectively. We observed strong positive correlation coefficients for $\mathrm{Cr}(R=0.803), \mathrm{Ga}(R=0.895)$, and $\mathrm{Kr}(R=0.852)$ at $\mathrm{PC} 1$, which is consistent with their strong positive correlation coefficients determined from the Pearson's correlation analysis (i.e., $\mathrm{Kr}$ vs. $\mathrm{Cr}(0.8 \leq R<0.9)$, $\mathrm{Kr}$ vs. Ga $(0.8 \leq R<0.9)$ ); this suggests that these three elements can be used as chemical markers for ship engine HFO combustion. We also observed positive correlations for $\mathrm{V}(R=0.842), \mathrm{Mn}(R=0.690), \mathrm{Ni}(R=0.596)$, and $\mathrm{Se}(R=0.552)$ at PC3. As previously mentioned in section 3.3, the high $E F$ value of Se (i.e., $E F>3$ ) suggests that

Table 5. Principal component analysis (Varimax rotation) of particulate elemental species collected at LCAS from May 2020 to June 2020.

\begin{tabular}{llllll}
\hline & \multicolumn{5}{c}{ Principal Component } \\
\cline { 2 - 6 } & PC1 & PC2 & PC3 & PC4 & PC5 \\
\hline $\mathrm{P}$ & -0.139 & $\mathbf{0 . 8 9 5}$ & 0.235 & 0.250 & -0.077 \\
$\mathrm{~S}$ & 0.176 & $\mathbf{0 . 9 2 6}$ & 0.161 & -0.040 & -0.111 \\
$\mathrm{Cl}$ & -0.460 & 0.566 & 0.099 & $\mathbf{0 . 4 9 9}$ & -0.105 \\
$\mathrm{Ti}$ & -0.063 & -0.184 & 0.209 & -0.297 & $\mathbf{0 . 8 1 8}$ \\
$\mathrm{V}$ & 0.186 & 0.227 & $\mathbf{0 . 8 4 2}$ & -0.007 & 0.040 \\
$\mathrm{Cr}$ & $\mathbf{0 . 8 0 3}$ & 0.097 & 0.410 & 0.320 & 0.111 \\
$\mathrm{Mn}$ & 0.470 & 0.022 & $\mathbf{0 . 6 9 0}$ & -0.143 & 0.002 \\
$\mathrm{Fe}$ & -0.337 & -0.194 & -0.183 & -0.878 & -0.156 \\
$\mathrm{Ni}$ & 0.338 & 0.462 & $\mathbf{0 . 5 9 6}$ & 0.225 & 0.147 \\
$\mathrm{Cu}$ & -0.173 & 0.050 & -0.099 & $\mathbf{0 . 9 0 7}$ & -0.261 \\
$\mathrm{Ga}$ & $\mathbf{0 . 8 9 5}$ & 0.053 & 0.274 & -0.178 & 0.153 \\
$\mathrm{As}$ & 0.708 & 0.496 & 0.205 & 0.169 & 0.073 \\
$\mathrm{Se}$ & 0.312 & 0.262 & $\mathbf{0 . 5 5 2}$ & 0.323 & 0.480 \\
$\mathrm{Br}$ & 0.318 & -0.048 & -0.049 & 0.088 & $\mathbf{0 . 9 1 0}$ \\
$\mathrm{Kr}$ & $\mathbf{0 . 8 5 2}$ & -0.314 & 0.304 & -0.001 & 0.164 \\
$\mathrm{Te}$ & 0.0392 & 0.282 & 0.484 & 0.365 & 0.200 \\
$\%$ of Variance & 23.8 & 17.7 & 16.5 & 15.5 & 12.4 \\
\hline
\end{tabular}


Table 6. Principal component analysis (Varimax rotation) of particulate elemental species collected at LTAS from May 2020 to June 2020.

\begin{tabular}{llllll}
\hline & \multicolumn{5}{c}{ Principal Component } \\
\cline { 2 - 6 } & PC1 & PC2 & PC3 & PC4 & PC5 \\
\hline $\mathrm{P}$ & 0.037 & 0.606 & -0.163 & 0.071 & 0.115 \\
$\mathrm{~S}$ & -0.191 & $\mathbf{0 . 8 7 3}$ & 0.149 & -0.139 & 0.061 \\
$\mathrm{Cl}$ & 0.089 & -0.320 & -0.098 & $\mathbf{0 . 8 3 3}$ & -0.030 \\
$\mathrm{Ti}$ & -0.122 & -0.265 & 0.304 & $-\mathbf{0 . 7 4 3}$ & -0.097 \\
$\mathrm{~V}$ & $\mathbf{0 . 7 2 7}$ & -0.380 & 0.124 & 0.085 & 0.319 \\
$\mathrm{Cr}$ & $\mathbf{0 . 8 0 8}$ & -0.206 & 0.168 & 0.308 & 0.316 \\
$\mathrm{Mn}$ & -0.110 & -0.129 & $-\mathbf{0 . 7 7 9}$ & 0.352 & -0.005 \\
$\mathrm{Fe}$ & -0.092 & -0.606 & -0.420 & -0.336 & -0.546 \\
$\mathrm{Ni}$ & 0.206 & 0.056 & $\mathbf{0 . 8 1 3}$ & 0.033 & -0.084 \\
$\mathrm{Cu}$ & -0.443 & -0.018 & $\mathbf{0 . 7 3 1}$ & 0.228 & 0.305 \\
$\mathrm{Ga}$ & $\mathbf{0 . 8 6 5}$ & 0.326 & -0.036 & -0.055 & -0.138 \\
$\mathrm{As}$ & 0.256 & 0.090 & 0.394 & $\mathbf{0 . 7 5 7}$ & -0.135 \\
$\mathrm{Se}$ & 0.670 & 0.073 & 0.056 & 0.053 & -0.157 \\
$\mathrm{Br}$ & 0.025 & 0.082 & -0.031 & -0.105 & $\mathbf{0 . 8 1 3}$ \\
$\mathrm{Kr}$ & 0.079 & $\mathbf{0 . 7 2 2}$ & 0.406 & -0.037 & -0.226 \\
$\mathrm{Te}$ & $\mathbf{0 . 6 9 8}$ & -0.435 & -0.060 & 0.221 & 0.465 \\
\% of Variance & 20.4 & 17.0 & 15.6 & 14.4 & 10.1 \\
\hline
\end{tabular}

Table 7. Principal component analysis (Varimax rotation) of particulate elemental species collected at WAAS from May 2020 to June 2020.

\begin{tabular}{llllll}
\hline & \multicolumn{5}{c}{ Principal Component } \\
\cline { 2 - 6 } & PC1 & PC2 & PC3 & PC4 & PC5 \\
\hline $\mathrm{P}$ & -0.237 & 0.055 & $\mathbf{0 . 9 1 0}$ & 0.015 & 0.111 \\
$\mathrm{~S}$ & 0.080 & 0.147 & $\mathbf{0 . 7 9 9}$ & 0.068 & 0.272 \\
$\mathrm{Ti}$ & -0.278 & $\mathbf{0 . 9 2 0}$ & -0.006 & -0.056 & -0.014 \\
$\mathrm{~V}$ & -0.080 & $\mathbf{0 . 9 4 8}$ & 0.047 & -0.019 & 0.059 \\
$\mathrm{Cr}$ & -0.061 & -0.021 & 0.038 & $\mathbf{0 . 9 9 3}$ & 0.040 \\
$\mathrm{Mn}$ & -0.101 & -0.069 & -0.022 & $\mathbf{0 . 9 8 7}$ & -0.005 \\
$\mathrm{Fe}$ & 0.088 & -0.266 & -0.283 & -0.352 & $-\mathbf{0 . 8 0 7}$ \\
$\mathrm{Ni}$ & $\mathbf{0 . 8 8 8}$ & -0.078 & 0.153 & -0.051 & -0.116 \\
$\mathrm{Cu}$ & -0.403 & $\mathbf{0 . 6 7 5}$ & 0.491 & -0.020 & -0.073 \\
$\mathrm{Ga}$ & $\mathbf{0 . 8 2 6}$ & -0.404 & -0.087 & -0.051 & 0.117 \\
$\mathrm{As}$ & -0.164 & -0.293 & 0.130 & -0.165 & $\mathbf{0 . 8 4 7}$ \\
$\mathrm{Se}$ & 0.146 & 0.015 & $\mathbf{0 . 7 8 1}$ & -0.037 & -0.054 \\
$\mathrm{Br}$ & 0.391 & 0.257 & -0.396 & -0.052 & 0.476 \\
$\mathrm{Kr}$ & $\mathbf{0 . 8 6 5}$ & -0.069 & 0.038 & -0.172 & -0.125 \\
$\mathrm{Te}$ & $\mathbf{0 . 6 5 8}$ & -0.412 & -0.349 & 0.114 & 0.007 \\
\% of Variance & 21.2 & 18.6 & 18.2 & 14.5 & 11.6 \\
\hline
\end{tabular}

Se can be used as a chemical tracer of industrial emissions; thus, the high positive correlations of other elements in PC3 (i.e., V, Mn, Ni, and Se) are also likely due to anthropogenic emissions from PIE1 industrial factories. Strong positive correlations between $\mathrm{Ti}, \mathrm{V}$, and $\mathrm{Cu}$ were also observed at PC2 (Table 7), which is likely explained by shipping emissions; PC2 contributed almost $18.6 \%$ (PC2) to the total variance-even at WAAS, which is the farthest sampling site from LCSP.

\section{CONCLUSIONS}

Both the first and the second-order derivatives of all SRXRF spectra exhibited prominent features at LCAS where ocean container vessels frequently dock to discharge and load containers. 
Our results suggest that $\mathrm{Ni} / \mathrm{V}$ can be used as an effective chemical tracer for aerosol identification from coal-fired power plant emissions. However, V/Fe was relatively ineffective at classifying shipping emissions, especially in atmospheric environments with high concentrations of iron-rich dust particles. Instead, $\mathrm{As} / \mathrm{V}$ and $\mathrm{Se} / \mathrm{V}$ can be used as alternative diagnostic binary ratios for classifying shipping emission aerosols. The extremely high $\log (E F)$ of Se detected at WAAS suggests that Se can be used as a chemical tracer of industrial emissions. We observed strong positive Pearson's correlation coefficients between numerous elements at LCAS, signifying the high contribution of ship engine HFO combustion to selected elements in the sea port area. HCA classified Fe as an outlier crustal element in all observation sites. Moreover, the closeness of $\mathrm{V}$, $\mathrm{Ti}, \mathrm{Ga}$, and $\mathrm{Ni}$ in the dendrograms indicated the strong influence of anthropogenic activities on the air quality at all monitoring stations. In addition, PCA highlights the importance of $\mathrm{Kr}, \mathrm{Cr}$, and $\mathrm{Ga}$ as three metals that can be used as chemical tracers for categorizing shipping emission aerosols. It is also crucial to highlight that the comparatively high correlation coefficients of $\mathrm{V}$, $\mathrm{Mn}, \mathrm{Ni}$, and Se detected at PC3 of LCAS can be interpreted as a consequence of industrial emissions during the observatory period. Overall, our findings highlight the possible use of SRXRF (a relatively rapid, highly sensitive, and non-destructive approach) to characterise shipping emission aerosols as well as other anthropogenically released particles.

\section{ACKNOWLEDGEMENTS}

This work was performed with the approval of the National Institute of Development Administration-Research Centre (NIDA-RC). The authors acknowledge all staff at Laem Chabang Sea Port Authority of Thailand for their assistance with air sample collection. The authors are also grateful to the Synchrotron Light Research Institute (Public Organisation), Ministry of Science and Technology, Thailand, for their contribution to the SRXRF measurements.

\section{FUNDING}

This work was supported by National Institute of Development Administration-Research Centre (NIDA-RC).

\section{SUPPLEMENTARY MATERIAL}

Supplementary material for this article can be found in the online version at https://doi. $\operatorname{org} / 10.4209 /$ aaqr. 210030

\section{REFERENCE}

Ahmad, I., Khan, B., Khan, S., Rahman, Zu, Khan, M.A., Gul, N. (2019). Airborne PM10 and lead concentrations at selected traffic junctions in Khyber Pakhtunkhwa, Pakistan: Implications for human health. Atmos. Pollut. Res. 10, 1320-1325. https://doi.org/10.1016/j.apr.2019.03.003

Aksoyoglu, S., Baltensperger, U., Prévôt, A.S.H. (2016). Contribution of ship emissions to the concentration and deposition of air pollutants in Europe. Atmos. Chem. Phys. 16, 1895-1906. https://doi.org/10.5194/acp-16-1895-2016

Almasoud, F.I., Usman, A.R., Al-Farraj, A.S. (2015). Heavy metals in the soils of the Arabian Gulf coast affected by industrial activities: Analysis and assessment using enrichment factor and multivariate analysis. Arab. J. Geosci. 8, 1691-1703. https://doi.org/10.1007/s12517-0141298-x

Almeida, T.S., Brancher, M., de Melo Lisboa, H., Franco, D., Maranhão, T.A., Borges, D.L.G. (2020). Direct analysis of particulate matter $\left(\mathrm{PM}_{10}\right)$ for the determination of $\mathrm{Be}, \mathrm{Cd}$ and $\mathrm{Pb}$ using high resolution-continuum source electrothermal atomic absorption spectrometry: Assessment of the potential correlation between analyte content and meteorological parameters. Spectrochim. Acta B 172, 105951. https://doi.org/10.1016/j.sab.2020.105951

Alves, C.A., Evtyugina, M., Vicente, A.M.P., Vicente, E.D., Nunes, T.V., Silva, P.M.A., Duarte, 
M.A.C., Pio, C.A., Amato, F., Querol, X. (2018). Chemical profiling of $\mathrm{PM}_{10}$ from urban road dust. Sci. Total Environ. 634, 41-51. https://doi.org/10.1016/j.scitotenv.2018.03.338

Báez, P.A., García, M.R., Torres, B.MdC., Padilla, H.G., Belmont, R.D., Amador, O.M., VillalobosPietrini, R. (2007). Origin of trace elements and inorganic ions in $\mathrm{PM}_{10}$ aerosols to the South of Mexico City. Atmos. Res. 85, 52-63. https://doi.org/ 10.1016/j.atmosres.2006.11.003

Barton, T.F. (1962). Thailand's rainfall distribution by geographic regions. J. Geogr. 61, 110-118. https://doi.org/10.1080/00221346208982121

Bhagavathy, V., Reddy, M.L.P., Sai, P.S.T., Rao, T.P., Damodaran, A.D. (1991). Preconcentration of rare earth quinolin-8-ol complexes onto activated carbon and determination by first-order derivative x-ray fluorescence spectrometry. Anal. Chim. Acta 242, 215-220. https://doi.org/10. 1016/0003-2670(91)87066-G

Bukowiecki, N., Hill, M., Gehrig, R., Zwicky, C.N., Lienemann, P., Hegedüs, F., Falkenberg, G., Weingartner, E., Baltensperger, U. (2005). Trace metals in ambient air: Hourly size-segregated mass concentrations determined by synchrotron-XRF. Environ. Sci. Technol. 39, 5754-5762. https://pubs.acs.org/doi/10.1021/es048089m

Bukowiecki, N., Lienemann, P., Zwicky, C.N., Furger, M., Richard, A., Falkenberg, G., Rickers, K., Grolimund, D., Borca, C., Hill, M., Gehrig, R., Baltensperger, U. (2008). X-ray fluorescence spectrometry for high throughput analysis of atmospheric aerosol samples: The benefits of synchrotron X-rays. Spectrochim. Acta B 63, 929-938. https://doi.org/10.1016/j.sab.2008.05.006

Cercasov, V., Pantelica, A., Sălăgean, M., Schreiber, H. (1998). Comparative evaluation of some pollutants in the airborne particulate matter in Eastern and Western Europe: Two-city study, Bucharest-Stuttgart. Environ. Pollut. 101, 331-337. https://doi.org/10.1016/S0269-7491(98)0 0059-1

Chu-Van, T., Surawski, N., Ristovski, Z., Yuan, C.S., Stevanovic, S., Ashrafur Rahman, S.M., Hossain, F.M., Guo, Y., Rainey, T., Brown, R.J. (2020). The effect of diesel fuel sulphur and vanadium on engine performance and emissions. Fuel 261, 116437. https://doi.org/10.1016/j.fuel.2019.116 437

Corbett, J.J., Lack, D.A., Winebrake, J.J., Harder, S., Silberman, J.A., Gold, M. (2010). Arctic shipping emissions inventories and future scenarios. Atmos. Chem. Phys. 10, 9689-9704. https://doi.org/10.5194/acp-10-9689-2010

Cozzi, F., Gržinić, G., Cozzutto, S., Barbieri, P., Bovenzi, M., Adami, G. (2012). Dimensional characterization of selected elements in airborne $\mathrm{PM}_{10}$ samples using $\mu$-SRXRF. X-Ray Spectrom. 41, 34-41. https://doi.org/10.1002/xrs.1377

Dai, Q.L., Bi, X.H., Wu, J.H., Zhang, Y.F., Wang, J., Xu, H., Yao, L., Jiao, L., Feng, Y.C. (2015). Characterization and source identification of heavy metals in ambient $\mathrm{PM}_{10}$ and $\mathrm{PM}_{2.5}$ in an integrated iron and steel industry zone compared with a background site. Aerosol Air Qual. Res. 15, 875-887. https://doi.org/10.4209/aaqr.2014.09.0226

Deng, S., Shi, Y., Liu, Y., Zhang, C., Wang, X., Cao, Q., Li, S., Zhang, F. (2014). Emission characteristics of $\mathrm{Cd}, \mathrm{Pb}$ and $\mathrm{Mn}$ from coal combustion: Field study at coal-fired power plants in China. Fuel Process. Technol. 126, 469-475. https://doi.org/10.1016/j.fuproc.2014.06.009

Di Gianfrancesco, A. (2017). 19 - Worldwide overview and trend for clean and efficient use of coal, in: Di Gianfrancesco, A. (Ed.), Materials for Ultra-Supercritical and Advanced UltraSupercritical Power Plants, Woodhead Publishing, pp. 643-687. https://doi.org/10.1016/B9780-08-100552-1.00019-1

Galvagno, S., Casu, S., Casabianca, T., Calabrese, A., Cornacchia, G. (2002). Pyrolysis process for the treatment of scrap tyres: Preliminary experimental results. Waste Manag. 22, 917-923. https://doi.org/10.1016/S0956-053X(02)00083-1

Gaonkar, C.V., Kumar, A., Matta, V.M., Kurian, S. (2020). Assessment of crustal element and trace metal concentrations in atmospheric particulate matter over a coastal city in the eastern Arabian Sea. J. Air Waste Manage. Assoc. 70, 78-92. https://doi.org/10.1080/10962247.2019. 1680458

Hong, Y., Shen, R., Cheng, H., Chen, Y., Zhang, Y., Liu, Y., Zhou, M., Yu, L., Liu, Y., Liu, Y. (2019). Estimating lead and zinc concentrations in peri-urban agricultural soils through reflectance spectroscopy: Effects of fractional-order derivative and random forest. Sci. Total Environ. 651 1969-1982. https://doi.org/10.1016/j.scitotenv.2018.09.391

Hsu, C.Y., Chiang, H.C., Lin, S.L., Chen, M.J., Lin, T.Y., Chen, Y.C. (2016). Elemental characterization 
and source apportionment of $\mathrm{PM}_{10}$ and $\mathrm{PM}_{2.5}$ in the western coastal area of central Taiwan. Sci. Total Environ. 541, 1139-1150. https://doi.org/10.1016/j.scitotenv.2015.09.122

Iavicoli, I., Fontana, L., Bergamaschi, A. (2009). The effects of metals as endocrine disruptors. J. Toxicol. Environ. Health B 12, 206-223. https://doi.org/10.1080/10937400902902062

Johansson, C., Norman, M., Burman, L. (2009). Road traffic emission factors for heavy metals. Atmos. Environ. 43, 4681-4688. https://doi.org/10.1016/j.atmosenv.2008.10.024

Lahiri, D., Nandini, G., Nayak, B. (2020). Synchrotron-(XRF, XRD, XAFS) techniques in advanced mineralogy. Aspects Min. Miner. Sci. 5, 563-564. https://doi.org/10.31031/AMMS.2020.05.00 0606

Lawson, D.R., Winchester, J.W. (1979). A standard crustal aerosol as a reference for elemental enrichment factors. Atmos. Environ. 13, 925-930. https://doi.org/10.1016/0004-6981(79)90003-9

Leili, M., Naddafi, K., Nabizadeh, R., Yunesian, M., Mesdaghinia, A. (2008). The study of TSP and $\mathrm{PM}_{10}$ concentration and their heavy metal content in central area of Tehran, Iran. Air Qual. Atmos. Health 1, 159-166. https://doi.org/10.1007/s11869-008-0021-z

Li, F., Ge, L., Tang, Z., Chen, Y., Wang, J. (2020). Recent developments on XRF spectra evaluation. Appl. Spectrosc. Rev. 55, 263-287. https://doi.org/10.1080/05704928.2019.1580715

Lim, J., Lee, J., Chung, Y. (2005). The distribution characteristics of trace elements in airborne particulates from an urban industrial complex area of Korea using instrumental neutron activation analysis. Nucl. Eng. Technol. 37, 503-510.

Lim, J.M., Lee, J.H., Moon, J.H., Chung, Y.S., Kim, K.H. (2010). Source apportionment of PM10 at a small industrial area using Positive Matrix Factorization. Atmos. Res. 95, 88-100. https://doi.org/10.1016/j.atmosres.2009.08.009

López, J.M., Callén, M.S., Murillo, R., García, T., Navarro, M.V., de la Cruz, M.T., Mastral, A.M. (2005). Levels of selected metals in ambient air $\mathrm{PM}_{10}$ in an urban site of Zaragoza (Spain). Environ. Res. 99, 58-67. https://doi.org/10.1016/j.envres.2005.01.007

López, M.L., Ceppi, S., Palancar, G.G., Olcese, L.E., Tirao, G., Toselli, B.M. (2011). Elemental concentration and source identification of $\mathrm{PM}_{10}$ and $\mathrm{PM}_{2.5}$ by SR-XRF in Córdoba City, Argentina. Atmos. Environ. 45, 5450-5457. https://doi.org/10.1016/j.atmosenv.2011.07.003

Maenhaut, W., Vermeylen, R., Claeys, M., Vercauteren, J., Roekens, E. (2016). Sources of the PM10 aerosol in Flanders, Belgium, and re-assessment of the contribution from wood burning. Sci. Total Environ. 562, 550-560. https://doi.org/10.1016/j.scitotenv.2016.04.074

Manoli, E., Voutsa, D., Samara, C. (2002). Chemical characterization and source identification/apportionment of fine and coarse air particles in Thessaloniki, Greece. Atmos. Environ. 36, 949-961. https://doi.org/10.1016/S1352-2310(01)00486-1

McDonald, M.A., Hildebrand, J.A., Wiggins, S.M. (2006). Increases in deep ocean ambient noise in the northeast Pacific west of San Nicolas Island, California. J. Acoust. Soc. Am. 120, 711-718. https://doi.org/10.1121/1.2216565

Mingorance, M.D., Valdés, B., Oliva, S.R. (2007). Strategies of heavy metal uptake by plants growing under industrial emissions. Environ. Int. 33, 514-520. https://doi.org/10.1016/j.envin t.2007.01.005

Mosher, B.W., Duce, R.A. (1987). A global atmospheric selenium budget. J. Geophys. Res. 92, 13289-13298. https://doi.org/10.1029/JD092iD11p13289

Nandini, G. (2020). Synchrotron-(XRF, XRD, XAFS) Techniques in Advanced Mineralogy. AMMS 5. https://doi.org/10.31031/AMMS.2020.05.000606

Nriagu, J.O. (1989). A global assessment of natural sources of atmospheric trace metals. Nature 338, 47-49. https://doi.org/10.1038/338047a0

Nriagu, J.O., Pacyna, J.M. (1988). Quantitative assessment of worldwide contamination of air, water and soils by trace metals. Nature 333, 134-139. https://doi.org/10.1038/333134a0

Olmer, N., Comer, B., Roy, B., Mao, X., Rutherford, D. (2017). Greenhouse Gas Emissions from Global Shipping, 2013-2015 Detailed Methodology. ICCT (the International Council on Clean Transportation), 52. https://theicct.org/sites/default/files/publications/Global-shipping-GHGemissions-2013-2015_ICCT-Report_17102017_vF.pdf

Pastuszka, J.S., Rogula-Kozłowska, W. ., Zajusz-Zubek, E. (2010). Characterization of PM10 and $\mathrm{PM}_{2.5}$ and associated heavy metals at the crossroads and urban background site in Zabrze, Upper Silesia, Poland, during the smog episodes. Environ. Monit. Assess. 168, 613-627. https://doi.org/10.1007/s10661-009-1138-8 
Philippat, C., Nakiwala, D., Calafat, A.M., Botton, J., De Agostini, M., Heude, B., Slama, R., EDEN. (2017). Prenatal exposure to nonpersistent endocrine disruptors and behavior in boys at 3 and 5 years. Environ. Health Perspect. 125, 097014. https://doi.org/10.1289/EHP1314

Pongpiachan, S., Hattayanone, M., Choochuay, C., Mekmok, R., Wuttijak, N., Ketratanakul, A. (2015). Enhanced $\mathrm{PM}_{10}$ bounded PAHs from shipping emissions. Atmos. Environ. 108, 13-19. https://doi.org/10.1016/j.atmosenv.2015.02.072

Pongpiachan, S., lijima, A. (2016). Assessment of selected metals in the ambient air PM10 in urban sites of Bangkok (Thailand). Environ. Sci. Pollut. Res. 23, 2948-2961. https://doi.org/10.1007/s 11356-015-5877-5

Pongpiachan, S., lijima, A., Cao, J. (2018). Hazard quotients, hazard indexes, and cancer risks of toxic metals in $\mathrm{PM}_{10}$ during firework displays. Atmosphere 9, 144. https://doi.org/10.3390/at mos9040144

Pongpiachan, S., Liu, S., Huang, R., Zhao, Z., Palakun, J., Kositanont, C., Cao, J. (2017). Variation in day-of-week and seasonal concentrations of atmospheric $\mathrm{PM}_{2.5}$-bound metals and associated health risks in Bangkok, Thailand. Arch. Environ. Contam. Toxicol. 72, 364-379. https://doi.org/ 10.1007/s00244-017-0382-0

Pongpiachan, S., Thumanu, K., Tanthanuch, W., Tipmanee, D., Kanchai, P., Schwarzer, K., Tancharakorn, S. (2013). Sedimentary features of tsunami backwash deposits as assessed by micro-beam synchrotron X-ray fluorescence ( $\mu$-SXRF) at the Siam photon laboratory. J. Tsunami Soc. Int. 32, 96-115.

Querol, X., Zhuang, X., Alastuey, A., Viana, M., Lv, W., Wang, Y., López, A., Zhu, Z., Wei, H., Xu, S. (2006). Speciation and sources of atmospheric aerosols in a highly industrialised emerging mega-city in Central China. J. Environ. Monit. 8, 1049-1059. https://doi.org/10.1039/B608768J

Ramírez, O., Sánchez de la Campa, A.M., Amato, F., Moreno, T., Silva, L.F., de la Rosa, J.D. (2019). Physicochemical characterization and sources of the thoracic fraction of road dust in a Latin American megacity. Sci. Total Environ. 652, 434-446. https://doi.org/10.1016/j.scitotenv.2018. 10.214

Rivers, M.L., Sutton, S.R., Jones, K.W. (1991). Synchrotron X-ray fluorescence microscopy. Synchrotron Radiat. News 4, 23-26. https://doi.org/10.1080/08940889108602607

Rudnick, R.L., Holland, H.D., Turekian, K.K. (2003). Treatise on geochemistry, Volume 3. Treatise on Geochemistry, 3, 659. ISBN 0-08-043751-6.

Sevimoğlu, O., Rogge, W.F. (2019). Seasonal variations of $\mathrm{PM}_{10}-$ Trace elements, PAHs and Levoglucosan: Rural sugarcane growing area versus coastal urban area in Southeastern Florida, USA. Part II: Elemental concentrations. Particuology 46, 99-108. https://doi.org/10.1016/j.par tic.2019.05.001

Sharma, S.K., Choudhary, N., Kotnala, G., Das, D., Mukherjee, S., Ghosh, A., Vijayan, N., Rai, A., Chatterjee, A., Mandal, T.K. (2020a). Wintertime carbonaceous species and trace metals in $\mathrm{PM}_{10}$ in Darjeeling: A high altitude town in the eastern Himalayas. Urban Clim. 34, 100668. https://doi.org/10.1016/j.uclim.2020.100668

Sharma, S.K., Choudhary, N., Srivastava, P., Naja, M., Vijayan, N., Kotnala, G., Mandal, T.K. (2020b). Variation of carbonaceous species and trace elements in $\mathrm{PM}_{10}$ at a mountain site in the central Himalayan region of India. J. Atmos. Chem. 77, 49-62. https://doi.org/10.1007/s10 874-020-09402-9

Solé, V.A., Papillon, E., Cotte, M., Walter, P., Susini, J.A. (2007). A multiplatform code for the analysis of energy-dispersive X-ray fluorescence spectra. Spectrochim. Acta B 62, 63-68. https://doi.org/10.1016/j.sab.2006.12.002

Taghavi, S.N., Kamani, H., Dehghani, M.H., Nabizadeh, R., Afshari, N., Mahvi, A.H. (2019). Assessment of heavy metals in street dusts of tehran using enrichment factor and geoaccumulation index. Health Scope 8, e57879. https://doi.org/10.5812/jhealthscope.57879

Tang, Y., Ma, X., Yu, Q., Zhang, C., Lai, Z., Zhang, X. (2015). Heavy metal enrichment characteristics in ash of municipal solid waste combustion in $\mathrm{CO}_{2} / \mathrm{O}_{2}$ atmosphere. Waste Manage. 43, 247254. https://doi.org/10.1016/j.wasman.2015.06.024

Tian, H., Cheng, K., Wang, Y., Zhao, D., Lu, L., Jia, W., Hao, J. (2012). Temporal and spatial variation characteristics of atmospheric emissions of $\mathrm{Cd}, \mathrm{Cr}$, and $\mathrm{Pb}$ from coal in China. Atmos. Environ. 50, 157-163. https://doi.org/10.1016/j.atmosenv.2011.12.045

Tian, H.Z., Wang, Y., Xue, Z.G., Cheng, K., Qu, Y.P., Chai, F.H., Hao, J.M. (2010). Trend and 
characteristics of atmospheric emissions of $\mathrm{Hg}$, As, and Se from coal combustion in China, 1980-2007. Atmos. Chem. Phys. 10, 11905-11919. https://doi.org/10.5194/acp-10-119052010

Tian, L., Ho, K.F., Louie, P.K.K., Qiu, H., Pun, V.C., Kan, H., Yu, I.T.S., Wong, T.W. (2013). Shipping emissions associated with increased cardiovascular hospitalizations. Atmos. Environ. 74, 320325. https://doi.org/10.1016/j.atmosenv.2013.04.014

Weckwerth, G. (2001). Verification of traffic emitted aerosol components in the ambient air of Cologne (Germany). Atmos. Environ. 35, 5525-5536. https://doi.org/10.1016/S1352-2310(01) 00234-5

Wen, J., Wang, X., Zhang, Y., Zhu, H., Chen, Q., Tian, Y., Shi, X., Shi, G., Feng, Y. (2018). PM2.5 source profiles and relative heavy metal risk of ship emissions: Source samples from diverse ships, engines, and navigation processes. Atmos. Environ. 191, 55-63. https://doi.org/10.1016/j.atm osenv.2018.07.038

Wu, S.P., Cai, M.J., Xu, C., Zhang, N., Zhou, J.B., Yan, J.P., Schwab, J.J., Yuan, C.S. (2020). Chemical nature of $\mathrm{PM}_{2.5}$ and $\mathrm{PM}_{10}$ in the coastal urban Xiamen, China: Insights into the impacts of shipping emissions and health risk. Atmos. Environ. 227, 117383. https://doi.org/10.1016/j.at mosenv.2020.117383

Yang, F., He, K., Ma, Y., Chen, X., Cadle, S.H., Tai, C., Mulawa, P.A. (2003). Characteristics and sources of trace elements in ambient $\mathrm{PM}_{2.5}$ in Beijing. Huan Jing ke xue 24, 33-37. https://europepmc.org/article/med/14768561

Zhang, Y., Wang, X., Chen, H., Yang, X., Chen, J., Allen, J.O. (2009). Source apportionment of leadcontaining aerosol particles in Shanghai using single particle mass spectrometry. Chemosphere 74, 501-507. https://doi.org/10.1016/j.chemosphere.2008.10.004

Zhao, J., Zhang, Y., Chang, J., Peng, S., Hong, N., Hu, J., Lv, J., Wang, T., Mao, H. (2020). Emission characteristics and temporal variation of PAHs and their derivatives from an ocean-going cargo vessel. Chemosphere 249, 126194. https://doi.org/10.1016/j.chemosphere.2020.126194

Zhao, J., Zhang, Y., Wang, T., Sun, L., Yang, Z., Lin, Y., Chen, Y., Mao, H. (2019). Characterization of $\mathrm{PM}_{2.5}$-bound polycyclic aromatic hydrocarbons and their derivatives (nitro-and oxy-PAHs) emissions from two ship engines under different operating conditions. Chemosphere 225, 4352. https://doi.org/10.1016/j.chemosphere.2019.03.022 